\title{
Investigating the effects of COVID-19 and public health expenditure on global supply chain operations: an empirical study
}

\author{
Xuanlong Qin ${ }^{1} \cdot$ Danish Iqbal Godil ${ }^{2} \cdot$ Muhammad Kamran Khan $^{3} \cdot$ Salman Sarwat ${ }^{4} \cdot$ Sadaf Alam $^{5} \cdot$ Laeeq Janjua $^{6}$
}

Received: 2 September 2020 / Revised: 29 November 2020 / Accepted: 18 December 2020/Published online: 6 January 2021

(C) The Author(s), under exclusive licence to Springer Science+Business Media, LLC part of Springer Nature 2021

\begin{abstract}
This fresh examination was a thought-provoking area that was required to be undertaken and to fill this gap, the researchers have examined the impact of Covid-19 and health expenditure on the global supply chain by utilizing balanced panel data for the period from January 2020 to June 2020. This study utilized a random effect, fixed effect, GMM, and FGLS approach. The outcomes of COVID-19 demonstrate a significant negative influence as per the FGLS model, whereas the health expenditure demonstrates a significant negative effect on the global supply chain under both the dynamic models i.e. GMM and FGLS. As far as manufacturing value-added is concerned it indicates a positive and significant influence on the global supply chain according to the FGLS model whereas, last but not least the logistics performance index has a significant positive effect on the global supply chain according to the results of GMM and FGLS models respectively. The global supply chain is the lifeline for the global economy; thus, it is suggested that under COVID-19 pandemic situation policymakers need to react quickly and take suitable policy actions to deal with this unprecedented pandemic driven economic crises and further the cross-border trading activities should not be stopped, rather governments should formulate smart lockdown strategies.
\end{abstract}

Keywords COVID-19 $\cdot$ Health expenditure $\cdot$ Logistics performance $\cdot$ Manufacturing industry

Laeeq Janjua

janjua.ue@gmail.com

Xuanlong Qin

qinxuanlong@chd.edu.com

Danish Iqbal Godil

danishiqbal.bukc@bahria.edu.pk

Muhammad Kamran Khan

kamrankhanaup@gmail.com

Salman Sarwat

salman.sarwat@bbsul.edu.pk

Sadaf Alam

salam.buic@bahria.edu.pk

1 College of Transportation Engineering, Chang' an University, Xi' an 710064, China

2 Business Studies Department, Bahria Business School, Bahria University Karachi Campus, Karachi, Pakistan

3 School of Economics, Northeast Normal University, Changchun, Jilin, China

4 Benazir Bhutto Shaheed University Lyari, Karachi, Pakistan

5 Bahria Business School, Bahria University Islamabad Campus, Islamabad, Pakistan

6 Poznan University of Economics, Poznan, Poland

\section{Introduction}

The management of a highly interrelated supply chain (SC) is an ever-boosting concern in a recent competitive business setting. Enhanced levels of chaos in the demand and the resulting supply, shorter technologies and life cycles of goods, globalized markets, and the enhanced usage of partners related to manufacturing, distribution, and logistics all result in a complicated global network. Considering the complications of numerous SCs, going through disruption is acknowledged by many businesses to be inevitable. It is not the SC system that encounters an issue, but it is the timing of the occurrence of a problematic happening and its severity.

Risks related to SC are diverse and can be classified into disruption risks and operational risk (Govindan et al. 2017; $\mathrm{Xu}$ et al. 2020). SC disturbances that are related to routine matters come under the umbrella of operational risk, for e.g. demand variations whereas, the low-frequency-highimpact occurrences are the part of risks related to disruptions (Hosseini et al. 2019). One particular situation of SC management disruptions is the pandemics. The present coronavirus (SARS-CoV-2/COVID-19) began from the city of Wuhan in China and instantly influenced Chinese trade and 
substantially decreased the supply accessibility in international SCs. According to Araz et al. (2020) this outbreak shows one of the significant disruptions that came across the past several years and is "breaking many global supply chains". The timeline for the initial stage of the pandemic is shown in Fig. 1.

Concerning China, the patients which were 292 on January 20, 2020, rose to 28,018 by February 05, 2020, and these cases were reached to 80,880 as on March 16, 2020 (Worldometers 2020). The drastic increase in the patients of COVID-19 between February to March has resulted in the closure of borders and quarantines in Europe, Asia, and the US. According to the announcement made by the World Health Organization (WHO) on August 6, 2020, there were $1,857,5326$ confirmed cases of COVID-19 which includes 701,754 deaths worldwide. (WHO Coronavirus Disease (COVID-19) Dashboard 2020). Figure 2 shows the regionwise situation as on August 6, 2020.

It was found out by Ivanov (2020) that the COVID-19 has uncovered the reality that SCs function are the veins of our society and economy. In another study Ivanov (2020) found that businesses all around the globe have encountered extraordinary challenges because of the interruptions triggered due to COVID-19 and the resultant lockdown. Individuals, in particular, have to deal with significant modifications in their lifestyle i.e. from self-isolation to the problems in the provision of essentials. A couple of businesses, primarily associated with hospitality industry were unable to continue due to the slump in trade, whereas other ventures have had to battle hard to fulfill the supply need of the society, such as farms,
Americas

$9,981,204$

confirmed

Europe

$3,451,556$

confirmed

South-East Asia

$2,360,721$

confirmed

Eastern Mediterranean

$1,585,458$

confirmed

Africa

848,053

confirmed

Western Pacific

347,593

confirmed

Fig. 2 Situation of COVID-19 (Region Wise). Source: World Health Organization

3rd party logistic, retailers, and the people associated with the field of health care SCs. Yet the fatality rate of individuals suffering from COVID-19 is less than other epidemics outbreaks that occurred earlier, its influence on the economies is more in the existing globalized community (World Economic Forum 2020). According to the Organization for Economic Co-operation and Development (2020) this pandemic is anticipated to slash the growth rate in the global gross domestic product (GDP) by $1.5 \%$.

\section{Timeline}

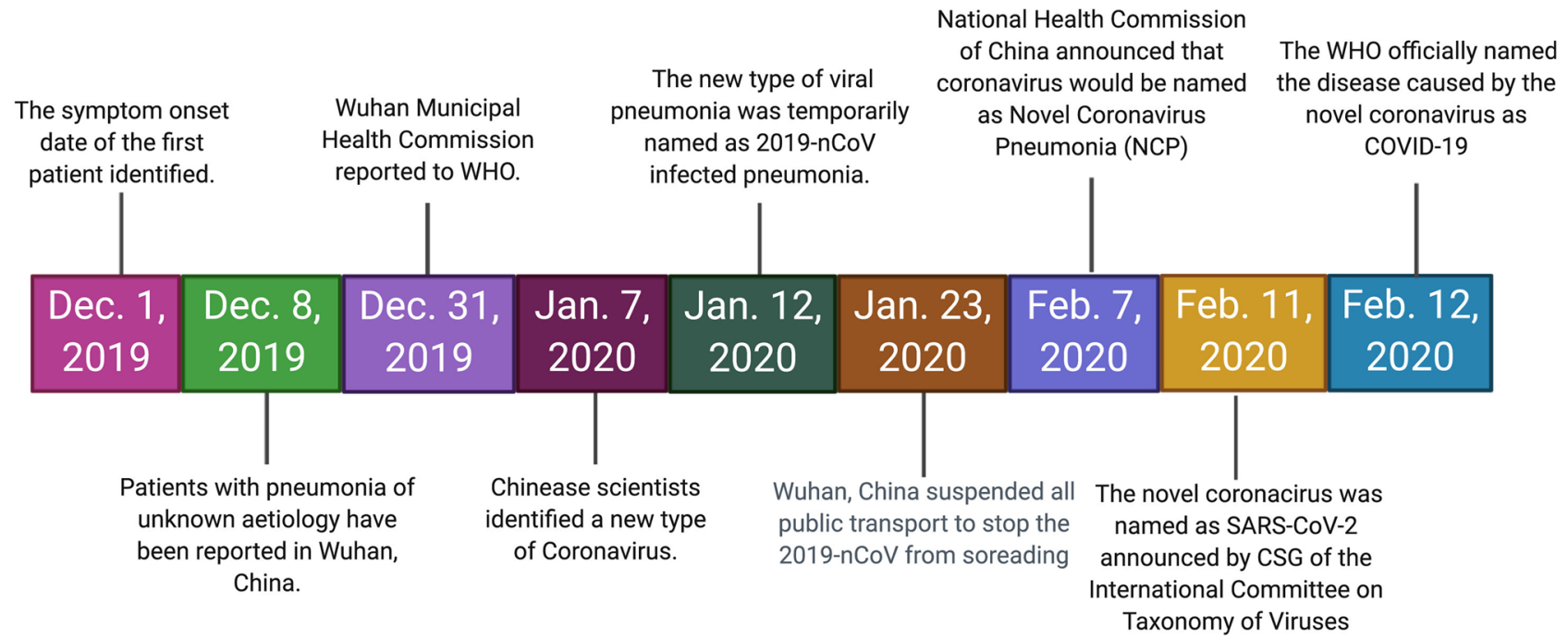

Fig. 1 Timeline showing the initial growth stage of COVID-19 [Yan et al. 2020] 
Due to the pandemic, people associated with medical and health care services are under huge pressure and workload in addition to enhanced health expenditures (HE). According to WHO estimation, in response to COVID-19 approximately 1.7 billion US $\$$ is required until December 2020 (COVID-19 Contributions Tracker 2020) Improving health is a crucial social objective these days, which has its direct and obvious payoffs with respect to better and longer lives for millions. Further, the idea is increasingly developing that enhancing health might have equal significant indirect payoffs by means of boosting economic growth (EG) (Gallup et al. 2001; Bloom and Canning 2005). For e.g. according to Gallup et al. (2001) freeing sub-Saharan Africa from Malaria could upsurge the yearly per capita growth up to $2.6 \%$ of that continent. Haseeb et al. (2019) found that EG may perhaps be seen as a consequence of an upsurge in the HE. Even though the health care setup is quite developed in Europe but even then the people of Europe see the COVID-19 pandemics as an anticipated health crisis that has a strong influence on the system of health care and the economies in specific regions of Europe (Buheji 2020). Figure 3 depicts the graphical picture of HE-trade nexus.

There might be certain factors behind the bilateral nexus between HE and GDP. Maximizing HE in a nation results in the increase in tranquility, social security, welfare, and safety, which contribute to improved efficiency of labor. $\mathrm{HE}$ enables people with severe issues to recover and get back to work as early as possible. Bloom et al. (2005) found that healthier individuals can work harder and for longer hours and also able to think more clearly. Numerous microeconomic researches have exhibited that health benefits related to insurance or HE influences the working environment of ill people (Ventelou et al. 2012; Bloom et al. 2005). Then again, at the macro level, there are less

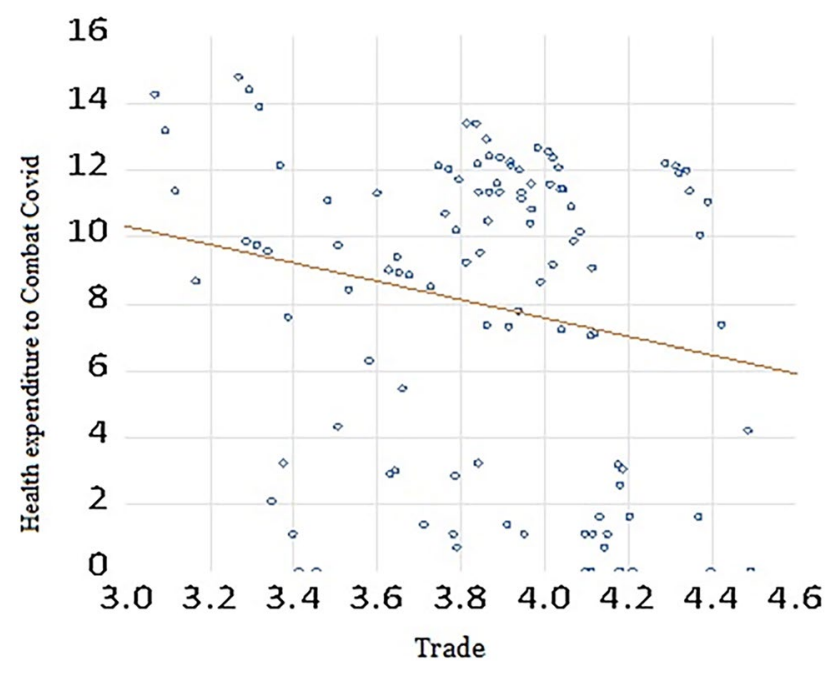

Fig. 3 Nexus between health expenditure and international trade researches on this subject matter perhaps because it is hard to disentangle the course of the HE-GDP nexus. Although the research on dealing with epidemic outbreaks from the human-centered logistics perspective offers a mature body of insights (Koyuncu et al. 2010, Green 2012, Altay et al. 2014, Anparasan et al. 2018, Farahani et al. 2020), the literary works on evaluating the influences of such pandemics on the SCs associated with the business is hard to find. Here the researchers found this as a research gap and a chance to put in considerable efforts. Thus, this study investigates the impact of Covid-19 and HE on global SC.

The outstanding part of this research covers four subdivisions. Section 2 contains a literature review of researchers related to the COVID-19, HE and SC, Sect. 3 is related to the methodology, construction of the model, and development of hypotheses. Analysis of data and related discussion is undertaken in Sect. 4, At last, Sect. 5, depicts the conclusion drawn from the outcomes and policy recommendations.

\section{Theoretical framework and hypotheses development}

Different facets of economic activities, like public infrastructures, exports, foreign direct investment (FDI), trade, human capital, and financial advancement, proximity to bigger markets, location costs, and institutional background have been determined as potential determinants of EG. ITR is also a significant component of the EG of the worldwide economy. However, disruption may result in a negative outcome as far as ITR and resulting EG is concerned. The SC disruptions have a substantial influence on the entire SC short term related performance. Besides, the $\mathrm{SC}$ disruptions also have a long-term negative influence on the entire SC financial performance. According to Hendricks and Singhal (2005), some businesses have suffered from the SC disruptions encountered 33\%-40\% lesser stock returns compared to their business benchmarks (Hendricks and Singhal 2005).

\subsection{Logistics industry and international trade}

Logistics is a substantial component of an SC. The progress of ITR and the growing number of destinations boost the significance of global logistics as an underlying aspect of the international economy. The efficiency of logistics networks is commonly known as a vital empowering aspect of international trade (ITR). Several studies have revealed a high nexus between enhanced logistic performance (LP) and boosted trade. According to Gani (2017), the services related to logistics and transport improve ITR and play a crucial role in the advancement and growth of the regional economy. The efficiency and quality of services related to logistics are vital for ITR as, a weak infrastructure of logistics processes associated with operations can 
be a significant barrier to the integration of ITR (Khan et al. 2020b; Khan et al. 2018; Devlin et al. 2005). However, a superior logistics-related trade, blended with a liberalized economic setting, can upsurge trade and economies of scale in production and distribution pursuits (Khan et al. 2020a; Lakshmanan et al. 2001).

Current studies on the logistics-trade nexus usually reveal consistent results and point to a standard course that the logistics-trade nexus is positively associated. For instance, Arvis et al. (2010) delivered descriptive statistics recommending a positive nexus between LP and trade openness. The study of Dollar et al. (2004) revealed that organizations in nations can achieve improved profits by boosting exports if better logistics and climate related to investment is available. Dee et al. (2006) found that the standard of infrastructure is linked with a significant upsurge in trade. Saslavsky and Shepherd (2012) validated that LP matters more for trade associated with GVCs as compared to other kinds of trade.

Hoekman et al. (2010) disclosed a significant positive LP-trade intensity nexus. Yip (2012) utilized gravity modeling to evaluate the trade of grain between the developing and developed nations, displaying distance (symbolizing cost of transportation) as substantial friction. In the evaluation, Hausman et al. (2012) contended that LP between two nations can be a major factor of total landed cost. It was argued by Arvis et al. (2012) that geographical distance and logistics and transport add the same to the costs of ITR. Limao et al. (2001) discovered a strong statistical association between the cost of transport and ITR flows. According to Luttermann (2020) LP, is highly linked with investment and trade. The outcomes of this study prove the same i.e. a significant nexus between LP and trade along with FDI. From the above discussion, the following hypothesis can be deduced:

- H1: Logistics performance has a significant influence on international trade.

\subsection{Health expenditure and international trade}

Governments are confronted with a complicated set of issues that makes it extremely challenging to furnish health services to their communities. Especially in the scenario of the current pandemic, where HE to cope with COVID-19 has risen dramatically. Balle and Vaidya (2002) highlighted the nexus between ITR and openness to the nation's government size as well as to particular classifications of spending by the government. At the state level, a higher extent of openness indeed has its cost, particularly it enhances spending on public welfare and health. This implies that the response of the government to the enhanced activities of ITR by rendering higher social protection.

High EG rates are generally related to high HE rates (Farag et al. 2013). But, the direction of causal nexus has been matter to discussions. Earlier researches furnished mixed outcomes by utilizing varied datasets, premise, and approximation strategies for nations throughout income clusters. Halici-Tuluce et al. (2016) explained the discoveries of the particular literature that examines this nexus and revealed contradictions in the causality direction. Both Ke et al. (2011), as well as Chen et al. (2013), concluded that the rate of HE growth differs at various levels of EG.

Bloom et al. (2004) found that FDI is also influenced by the healthy workers, as businesses are not willing to engage in the activities of nations with a high level of diseases and mortality. When the information is segregated according to the variations in income across nations it was discovered that more trade openness is related to larger spending by the government in low-income nations however for high-income nations this nexus was not true in aggregate. Additionally, utilizing the disaggregated data of government spending, a significant and positive nexus with openness was revealed for spending on defense and overall health in low earning nations (Benarroch 2012). Hashmati (2001) utilized samples from OECD nations to evaluate the connection between HE and EG in the country. The researcher found a positive HE-EG nexus.

Some studies have also revealed the negative nexus between HE and EG. For example, a study by Kar et al. (2003) revealed a negative HE-EG nexus. Yumusak et al. (2009) utilized the time series data and reached to the same results, i.e. verifying a negative nexus between EG and HE in Turkey. According to the research of Oni (2014) concerning Nigeria's labor force work productivity, the formulation of gross capital and HE are significant factors. But, the poor health of employees and their life expectancy rates have a negative effect due to EG. Newhouse (1992) and Eggoh et al. (2015) discovered that higher HE and poor health of labor not only curtail economic activities but also upsurge the rate of unemployment and generate pressure on the nation's EG for the long term. According to Rodrik (1998) under none of the cases, there was a significant nexus between spending on social security and openness. From the above discussion, the following hypothesis can be deduced:

- H2: Health expenditure has a significant influence on international trade.

\subsection{SARS-COV-19 and international trade}

Buheji (2020) revealed that the economic influence of the COVID-19 can be presented through three potential conditions, the influence on labor productivity because the major influences come from employees unable to perform their job, causing an average drop in the productivity of labor by $1.4 \%$ during the course of 2020. Further, the COVID-19 triggers a shock on total factor productivity the influences of which are being experienced through a transient paralysis of local canonic activity due 
to interruptions in distribution channels and the inability to render services and inputs. All this was because of quarantine for a workforce which resulted in the reduction of worldwide GDP by $1 \%$. The last is a trade impact. Here, the influences were due to the disruption in the ITR, resulted in an upsurge in the cost of carrying out the trade by approximately $5 \%$ and was sufficient to stimulate a global cost of EG by $1 \%$ (Vos et al. 2020).

Being globalized and lean in structures, the SCs of numerous businesses became particularly susceptible to the outbreaks. About $94 \%$ of the Fortune 1000 businesses have suffered from SC disruptions because of COVID-19. A report issued by Dun and Bradstreet, a corporate firm of data analytics that 51,000 businesses all around the globe have at least one direct suppliers in the region of Wuhan, and near about 5 million businesses around the globe have at least tier-two suppliers in the COVID-19's origin i.e. Wuhan. Additionally, 938 of the Fortune 1000 businesses have either the tier-one or the tier-two suppliers in the region of Wuhan (Dun et al. 2020). Linton et al. (2020) found that in the quarantine areas related to the COVID-19, over 12,000 establishments such as warehouses, factories, and other operations are owned by $1,000 \mathrm{SCs}$ that are world's largest.

Concerning SCs activities rare facts are found on earlier epidemic outbreaks. Johanis (2007) revealed the pandemic feedback plan designed at the International Airport of Toronto Pearson adhering to the implications of the SARS epidemic outbreak during 2002-2003. SARS has a negative influence on the airline industry, due to the suspension of about $30 \%$ of international flights specifically in Taiwan (Chou et al. 2004). Figure 4 shows the position of transport and aviation in the $1^{\text {st }}$ quarter of 2020.

Though at the times of SARS, China was playing differently from the current situation with respect to SCs, and the influences of SARS on the global SCs have been comparatively low. The spread of the Ebola virus has adversely influenced international logistics (BSI 2014). Calnan et al. (2018) explain the lessons that were figured out during the Ebola era and pointed out to a need of developing a decision-support system which would assist anticipating the influences of these types of epidemics outbreaks on the global and local SCs and managing the functional and logistics procedures during the course of and following the crisis. It is natural to anticipate a decline in operational results, EBIT, etc., shortages of material, and variations in prices during widespread outbreaks. This verifies the examination of reports related to coronavirus. Like for example, German Post announced a reduction in EBIT within the range of 60 to 70 million euros; in February with respect to China, the retail prices increased by approximately 21.9\% (Bild 2020). On February 17, 2020, Apple reported anticipating a drop in its quarterly earnings (Apple 2020).

By the end of February 2020, due to this COVID19 outbreak, nearly $9 \%$ of shipping containers become inactive, and industrial indices of China strike at their lowest point ever since the Great Recession because of discontinuing the production operations to control the COVID-19 spread (Retaildive 2020). Foxconn the assembler of Apple is operating below capacity. Government lockdown has influenced the suppliers of Apple in Europe and Malaysia and is also facing the dearth of parts because of their sub-suppliers. According to a survey by ISM, about 600 US businesses exposed that suppliers are working at an average capacity of 50\% leading to extended final goods lead time for approximately $57 \%$ of surveyed businesses and an unfavorable revenue effect which ranges between $5.6 \%-15 \%$ (ISM 2020).

\section{Number of Flights}

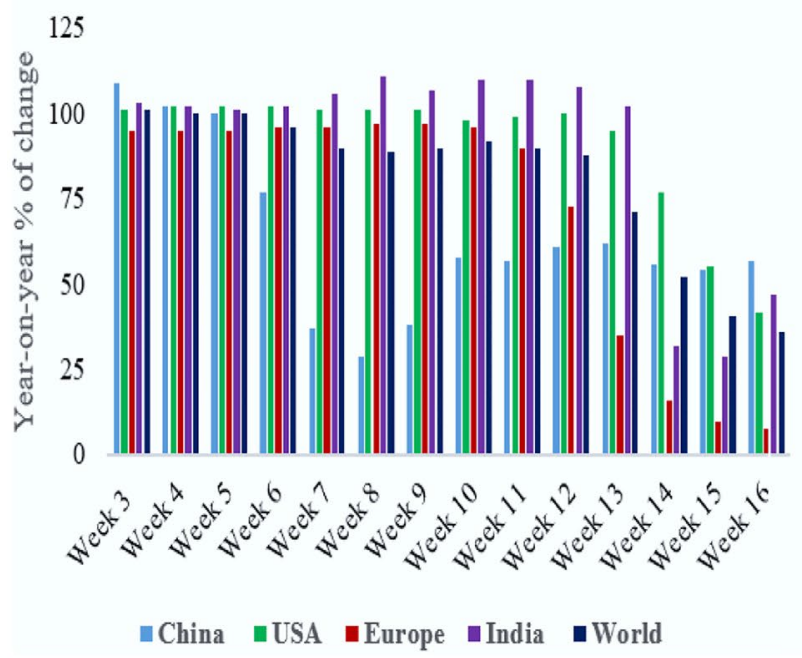

\section{Road Transport Activity}

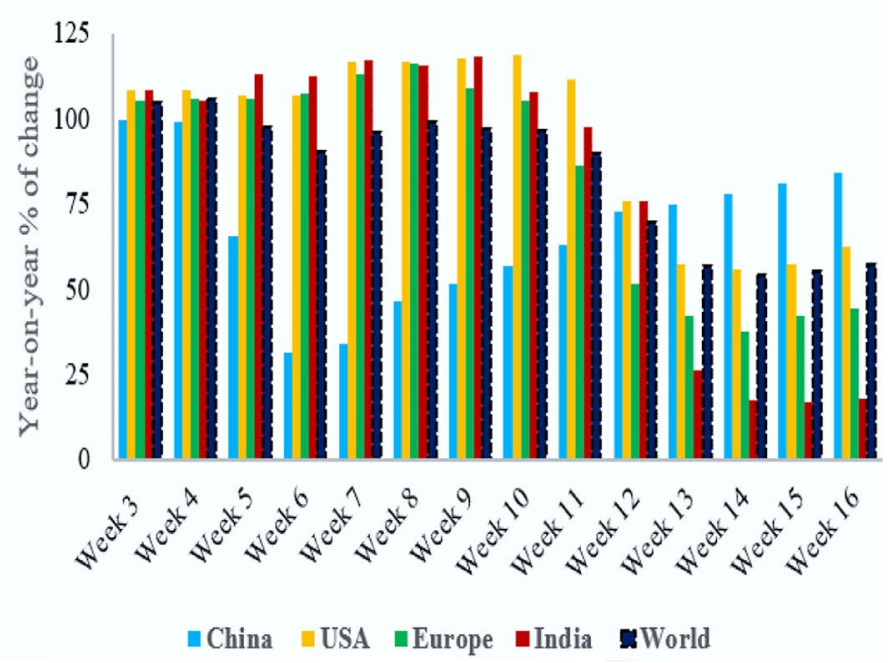

Fig. 4 Global transport and aviation position in the 1st quarter of 2020 (International Energy Agency 2020) 


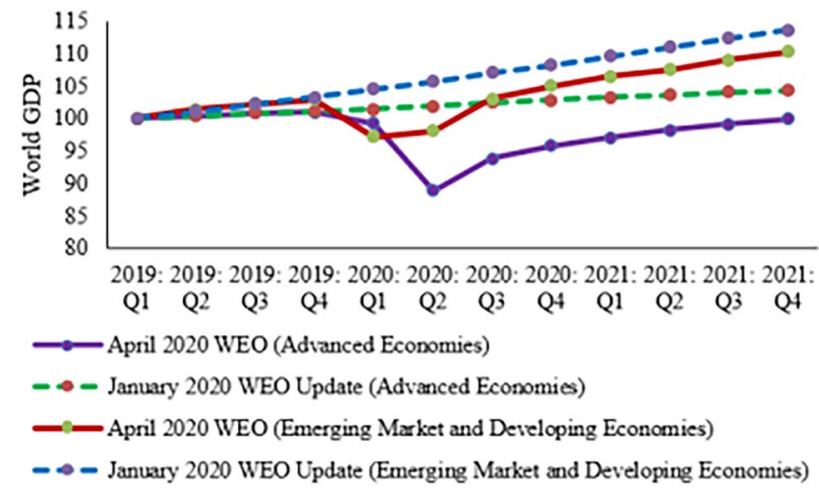

Fig. 5 Quarterly global GDP 2019: Q1=100, Dashed line indicate estimates from January, 2020 WEO (Mofijur et al., 2021)

Besides, household earnings, employment, and social welfare were influenced (European Commission 2020). The high COVID-19 confirmed cases in Europe had a damaging impact on manufacturing systems, a considerable decline in agricultural-related activities, trade, and tourism. This crisis has enormously influenced various businesses globally (see Figs 5 and 6). According to Kraus et al. (2020), government authorities across the US and Europe have executed monetary first-aid and stimulus plans for businesses. Although some sectors particularly healthcare have encountered enhanced demand and are in fact benefiting from the situation. An evident drop was resulted in the revenues of the tourism and hospitality sector due to government regulations related to COVID19. However, concerning restaurants, pickups, and food delivery was allowed. Industries related to leisure activities such as (cinemas, museums, sports areas) were also severely affected. From the above discussion, the following hypothesis can be deduced:

- H3: COVID-19 has a significant influence on international trade.

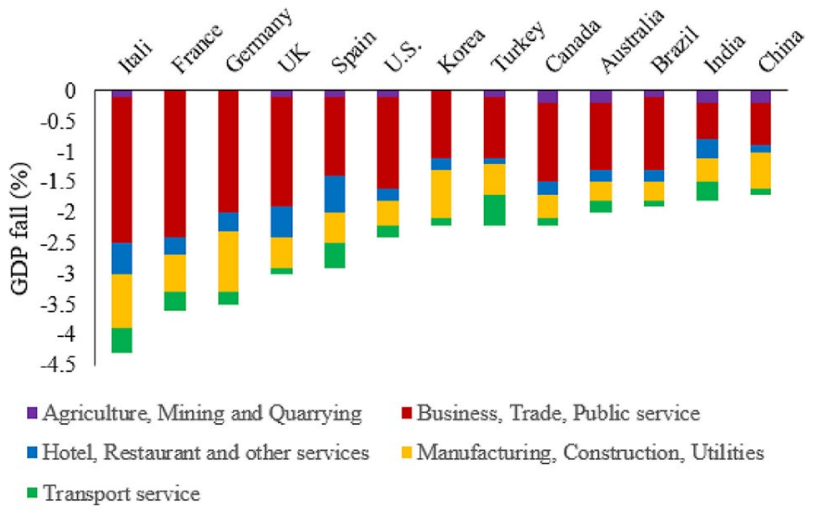

Fig. 6 Fall in GDP due to lockdown in selected countries (Mofijur et al., 2021)

\subsection{Manufacturing industry and international trade}

During the previous several years, structural variations taking place in the international economy have redesigned international manufacturing and ITR leading to variations in the organization of manufacturing setups. The strong and robust industrial base of Italy and its swift boost in services have resulted in substantial pressure on the utilization of energy in the preceding years, and since 1988 the nation has been incurring constant trade surpluses due to the reduced imports and enhanced exports (Cerdeira Bento and Moutinho 2016). Similarly, Wakasugi (2007) investigated the trade expansion in East Asia and indicates that it has been associated with a significant boost in the portion of vertical intra-industry trade stimulated by the global fragmentation of manufacturing. Production is fragmented into various phases, which are then carried out in specific plants situated in different nations, more intermediate products circulate between nations (Cabral and Amador 2015). Bernard et al. (2012) discover that a considerable percent of companies' exports in Belgium is consists of items that are not manufactured by the company, marked as "carry-along trade" (CAT).

Engemann and Lindemann (2013) discovered that multinationals firms of Germany typically identify affiliates that manufacture products positioned at subsequent phases of the manufacturing procedure in more productive nations. By utilizing the data at the firm level of US multinationals, Hanson et al. (2005) examined trade in intermediate items between parent companies and foreign associates. They determine that importing inputs from the affiliates are more in host nations with a lower cost of trade, wages for semi-skilled workers, and corporate tax. A couple of current research works (e.g., Kasahara et al. 2008; Fernandes 2007) have revealed the positive effect of intermediate products trade on the productivity of firms.

The outcomes of research conducted by Bas and StraussKahn (2014) unveil that importing greater varieties of inputs upsurge the number of varieties exported not just because of productivity gains but also by using other direct options. According to Melitz (2003), to be an exporter businesses need a specific amount of productivity. It was found in a study of Portugal-Perez et al. (2012) that measures taken for trade facilitation not merely boosted imports but additionally enhanced exports by using better accessibility to inputs for manufacturing and greater engagement in regional and international value chains. The portion of services in the global GDP has much exceeded the portion of production, the worldwide merchandise trade has expanded at a faster pace than worldwide manufacturing of merchandise (WTO 2016).

Concerning developing nations, the degree of industrialization has a positive nexus with per capita income. The developing nations which have higher per capita earnings 
have noticed the share of production in GDP and upsurge in employment (Haraguchi et al. 2017). It is generally believed that in global scenario manufacturing-related jobs are decreasing (Ghani and O'Connel 2014). Thus, even if manufacturing can retain at the same level, it might be regarded as playing a less significant role because of its weakened potential to boost EG. The manufacturing segment provides special opportunities for the formation of capital. The formation of capital is among the aggregate means of growth (Szirmai 2009; Khan et al. 2019). It is considerably lower in services and agriculture; therefore, a boosting share of production will contribute to EG.

Tregenna (2007) examined the importance of industrialization for EG of South Africa and indicates that the manufacturing sector is important because of its strong backward connections to the service and other sectors. According to Katuria and Raj (2009), more industrialized regions develop more swiftly. Chakravarty et al. (2009) also supported the notion that manufacturing is one of the factors behind overall EG. By utilizing the panel data the nexus between the proportion of service and production industry to GDP growth per capita and GDP was evaluated by Szirmai and Verspagen (2015). Both developing and developed nations were taken as samples for three periods i.e. first from 1950-70, second from 1970-90, and third from 1990-2005. The outcome depicted that manufacturing works as a growth engine for low together with some nations having a middlelevel income, provided that these nations have an adequate level of human capital.

Concentrating on economies with middle-level income, Su and Yao (2017) evaluated whether the production sector inspires the services sector growth. The results prove the same i.e. the development of the service sector is led by the industrial sector and the case was not vice versa. So it was concluded by the authors that for economies, manufacturing is in fact the growth engine and, consequently, that the de-industrialization at early stages has a damaging effect on EG. Success in EG was similar to industrialization (Attiah 2019). The analysis carried out by Attiah (2019) on 40 developing and 10 developed nations from 1950-2015 revealed that the portion of manufacturing is positively associated with EG and this influence is more noticeable for the poorer nations. The same positive association between EG and the manufacturing sector was found out by Banjoko et al. (2012) in the case of India, China, Singapore, North Korea, and Malaysia. An assessment between the numerous nations" exports and their GDP (per capita) reveals that exports are done by manufacturers still prevail among the nations that have the highest per capita GDP among other countries of the world (Haraguchi et al. 2017). From the above discussion, the following hypothesis can be deduced:

- H4: The manufacturing industry has a significant influence on international trade.

\section{Data source and material}

The main emphasis of this study is to explore the influence of COVID-19, logistic industry, manufacturing industry and health expenditure on the global supply chain in a group of eighteen countries, including Australia, Argentina, Canada, Brazil, China, Germany, France, India, Italy, Indonesia, Japan, Russian Federation, Mexico, Saudi Arabia, Turkey, United Kingdom, South Africa, and United States; by utilizing balanced panel data for the period from January 2020 to June 2020. To examine the above-mentioned objective; this study utilized random effect, fixed effect, GMM, and FGLS models. Data were gathered from different sources as depicted in Table 1.

Further, the conceptual framework is presented in Fig. 7. The following equation is based on the model.

$I T R_{i t}=\beta_{0}+\beta_{1} H E_{i t}+\beta_{2} M F V D_{i t}+\beta_{3} L P_{i t}+\beta_{4} C O V I D_{i t}+\varphi_{t}+\varepsilon_{i t}$

In the above equation, ITR is international trade as a percentage of GDP used as a proxy for measuring the global supply chain, HE is the health expenditure as a percentage of GDP associated to Covid-19, MFVD indicates the manufacturing value-added as a percentage of GDP, logistic performance index is denoted by the LP and COVID indicates the Covid-19 active cases in the study countries under study. $\varepsilon$ Denotes the error term in the above model while $\beta_{0}$ specify the constant term in the model while $\beta_{1}$ to $\beta_{4}$ represent the coefficients of the independent variables.

\begin{tabular}{lll}
\hline Variable & Period & Source \\
\hline $\begin{array}{l}\text { Global Trade \% of GDP (proxy of global supply chain } \\
\text { Operations) }\end{array}$ & Jan 2020 to June 2020 & Statistica (2020) \\
Health expenditure \% of GDP to Combat Covid-19 & Jan 2020 to June 2020 & Statistica (2020) \\
Manufacturing Value-added \% of GDP & Jan 2020 to June 2020 & World Bank (2020) \\
Logistic performance index & Jan 2020 to June 2020 & Statistica (2020) \\
Covid-19 (Active cases) & Jan 2020 to June 2020 & COVID-19 world meter \\
\hline
\end{tabular}


Fig. 7 Conceptual framework

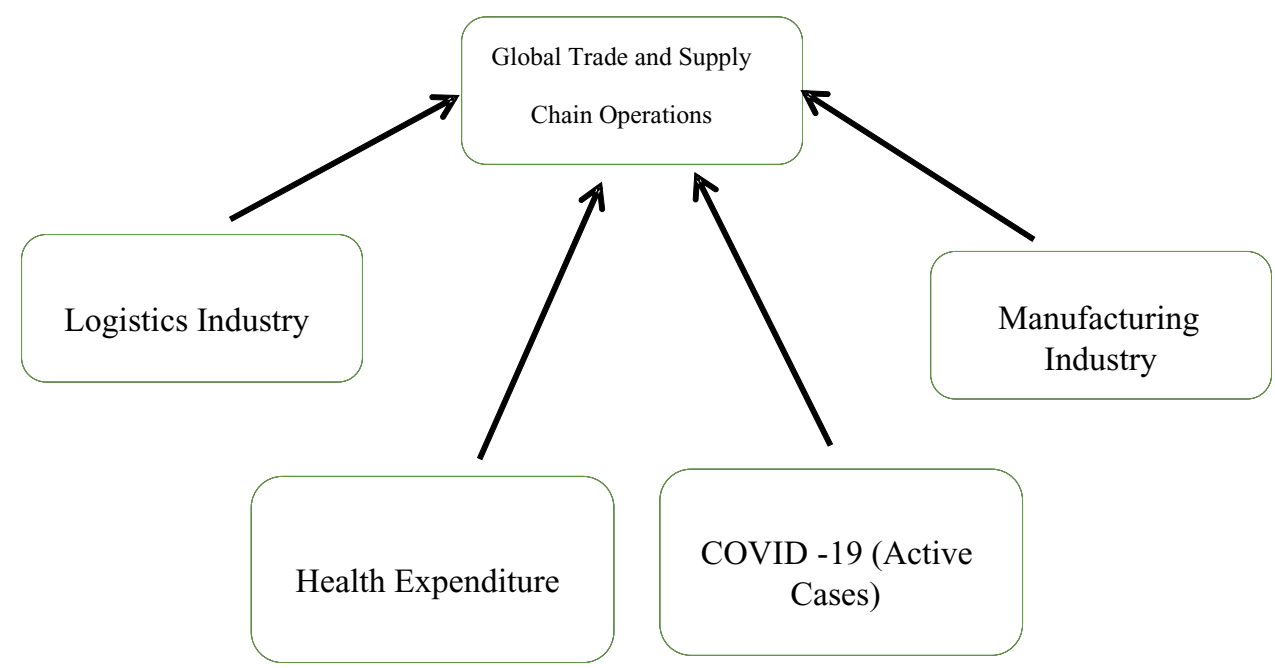

In panel data models, fixed effects model indicates the relation of unidentified form amongst the error term and independent variables; additionally, the error term and the individual-specific effect essentially should not be correlated. On the other hand, the random effect model is known as the competitor of the fixed-effect model. Greene (2011) revealed that the random effect model indicates that the individual-exact impact is a random variable that has no correlation with independent variables; while, if the individual-exact impact is certainly not correlated; then the random effect model is considered most appropriate as compared to the fixed effect model in panel data models. However, the choice between random and fixed effect models is decided with the help of the Hausman test.

The generalized method of moments (GMM) is a dynamic econometric model that is proposed by Arellano and Bond (1991); the GMM model is utilized because the simple OLS model might lead to diverse econometric predicaments. Heteroskedasticity and autocorrelation are the main problems that have to be faced during the analysis of panel data; that cause incorrect results estimation. Attari et al. (2016) revealed that the problem of autocorrelation occurs in term of disruption in the econometric model with any observed variables that have not impacted by the disruption term interrelated with other variables, while Simpson (2012) indicated that issue of heteroskedasticity normally occurs in panel data that is caused by the variance of the error term. Judge et al. (1985), and Maddala and Lahiri (1992) revealed that Feasible GLS (FGLS) resolves the issues of heteroskedasticity and serial correlation in the model. Greene (2012), and Davidson and Mackinnon (1993) indicated that in Feasible GLS (FGLS) model, heteroskedasticity issue is permitted but with the condition of no correlation across the crosssectional data, while asymptotic efficiency is not suitable with a small size of the sample due to the variation caused by the estimated Feasible GLS (FGLS) model. In another research, Grilliches and Rao (1969) indicated that Feasible GLS (FGLS) is most appropriate as compared to OLS, FGLS fixes the issues of heteroskedasticity and autocorrelation in panel data estimation.

The first equation has the issues of unnoticed heterogeneity that is mainly caused by the country's fixed effect and the time effect. As suggested by Arellano and Bond (1991), heterogeneity problems can be solved with first difference estimators i.e. known as the dynamic panel model generalized method of moments; it also removes the problem of serial correlation and heterogeneity. In this paper, the same approach has been used. Besides, i depicts the number of sample 18 countries and $t$ specifies the time period utilized in the equations:

$$
\begin{array}{rl}
I T R_{i t}=\beta_{1} H E_{i t}+\beta_{2} M F & V D_{i t}+\beta_{3} L P_{i t}+\beta_{4} \text { COVID } \\
& +\varphi_{t}+\varepsilon_{i t}=\gamma_{i t} \delta+\varphi_{t}+\varepsilon_{i t}
\end{array}
$$

Newey and West (1994) indicated that $\gamma_{i t}$ is the term, used in the above equation, maybe exogenous variables with lags of regressors and regressand (Windmeijer (2000; Arellano and Bond 1991). $\delta$ Indicates the Kx1 coefficients of the independent variables, while $\mathrm{K}=\mathrm{g} 2+\mathrm{k} 1$.

\section{Results and discussion}

Table 2 demonstrates the results of descriptive statistics i.e. Number of observations, mean, standard deviation, minimum and maximum for each variable.

The examined results indicate that trade \% of the GDP has a mean value of 3.8391 with a fluctuation of 0.3403 that indicates variation in the trade around all countries. The minimum and maximum values of trade are 3.0229 and 4.4849 respectively. Means value of health expenditure related to Covid-19 is 2.1522 for all countries with a standard deviation 
Table 2 Descriptive statistics

\begin{tabular}{lllllr}
\hline Variable & Obs & Mean & Std. Dev & Min & Max \\
\hline Trade \% of GDP & 108 & 3.839103 & 0.340305 & 3.022953 & 4.484931 \\
Health expenditure \% of GDP to Combat Covid-19 & 108 & 2.152234 & 0.472055 & 1.094957 & 3.099175 \\
Manufacturing Value added \% of GDP & 108 & 2.511665 & 0.385587 & 1.508145 & 3.336088 \\
Logistic performance index & 108 & 1.241649 & 0.129383 & 0.944242 & 1.441248 \\
Covid-19 (Active cases) & 100 & 8.535145 & 4.210079 & 0 & 14.7664 \\
\hline
\end{tabular}

value 0.4720 during the Covid-19; the maximum and minimum value of health expenditure is 3.0991 and 1.0949 respectively. The means value of manufacturing values added and the logistic performance index is 2.5116 and 1.2416 with that conform that these two elements help to increase the volume of trade around the world while health expenditure and Covid-19 causes show negative relation with the global supply chain. The recent Covid-19 has adversely influenced

Table 3 Correlational matrix

\begin{tabular}{lcccc}
\hline & Trade \% of GDP & $\begin{array}{l}\text { Health expendi- } \\
\text { ture \% of GDP }\end{array}$ & $\begin{array}{l}\text { Manufacturing } \\
\text { Value-added \% of } \\
\text { GDP }\end{array}$ & $\begin{array}{l}\text { Logistic } \\
\text { performance } \\
\text { index }\end{array}$ \\
\hline Trade \% of GDP & 1 & & $\begin{array}{l}\text { Covid-19 } \\
\text { (Active } \\
\text { cases) }\end{array}$ \\
Health expenditure \% of GDP to Combat Covid-19 & -0.221 & 1 & & \\
Manufacturing Value added \% of GDP & 0.1138 & -0.4378 & 1 & 1 \\
Logistic performance index & 0.1473 & 0.6321 & -0.1237 & 0.0575 \\
Covid-19 (Active cases) & -0.1502 & 0.2669 & -0.0893 & 1 \\
\hline
\end{tabular}

standard deviation values 0.3855 and 0.1293 respectively. Covid-19 active cases indicate the highest mean value i.e. 8.535 with the highest variation value 4.21 .

Table 3 indicates the results of the correlation matrix. The correlation matrix is used to examine the association amongst the study variables. The examined results indicate that the global supply chain has a positive relationship with manufacturing value-added and logistic performance index the global economy that ultimately negatively impacted the global supply chain.

Table 4 demonstrates the results of fixed effect, Random effect, GMM, and FGLS respectively. The examined result of the fixed effect indicates that health expenditure has a positive and significant effect on the global supply chain while the result of the random effect is insignificant. On the other hand, the results of the dynamic model i.e. GMM

Table 4 Regression estimations

\begin{tabular}{lllll}
\hline Variable & Fixed effect & Random Effect & GMM & FGLS \\
\hline Health expenditure \% of GDP to Combat Covid-19 & $0.331^{*}$ & 0.117 & $-0.444^{* * *}$ & $-0.378^{* * *}$ \\
& $(0.178)$ & $(0.143)$ & $(0.107)$ & $(0.0968)$ \\
Manufacturing Value added \% of GDP & $0.418^{* * *}$ & $0.260^{* *}$ & -0.076 & $0.0870^{* *}$ \\
& $(0.154)$ & $(0.130)$ & $(0.0939$ & $(0.0874)$ \\
Logistic performance index & -0.323 & -0.0171 & $1.675^{* * *}$ & $1.175^{* * *}$ \\
& $(0.465)$ & $(0.401)$ & $(0.3946)$ & $(0.311)$ \\
Covid-19 ( Active cases) & $-0.0123^{* * *}$ & $-0.0102^{* * *}$ & -0.0067 & $-0.00320^{*}$ \\
& $(0.00403)$ & $(0.00361)$ & $(0.3143)$ & $(0.00754)$ \\
Constant & $2.567^{* * *}$ & $3.035^{* * *}$ & $2.6237^{* * *}$ & $3.426^{* * *}$ \\
& $(0.739)$ & $(0.586)$ & $(0.5182)$ & $(0.377)$ \\
Hausman & 0.1500 & & - & - \\
Observations & 108 & 108 & 108 & 108 \\
Number of Countries & 18 & 18 & 18 & 18 \\
\hline
\end{tabular}

Standard errors in parentheses

$* * * \mathrm{p}<0.01, * * \mathrm{p}<0.05, * \mathrm{p}<0.1$ 
and FGLS demonstrate a significant negative effect of HE on the global supply chain around the study countries. The observed results of GMM and FGLS model show that the increase in health-related expenditure adversely influences the global supply chain; $1 \%$ increase in health expenditure as a ratio of GDP will cause a decline of the global supply chain by $0.44 \%$ and $0.378 \%$ as per GMM and FGLS methods respectively. Asteriou (2009) indicated that healthrelated foreign aid helps to increase economic growth. In a recent study, Khan et al. (2020) revealed that health expenditures negatively influence the economic growth that adversely influences the global supply chain. Kar and Taban (2003) indicated that health expenditure has a negative association with the economic growth; similar results were pointed out by Yumusak and Yıldırım (2009), they indicated that the health expenditure negatively influences the economic growth in turkey.

Manufacturing value added takes into account the total production of all manufacturing units in the country. The examined results of manufacturing value-added indicate positive and significant influence on the global supply chain according to fixed effect, random effect and FGLS model, as 1\% increase in manufacturing value-added as a percentage of GDP may cause an upsurge of $0.418 \%, 0.26 \%$, and $0.087 \%$ respectively in the global supply chain. Manufacturing is considered an essential part of economic growth in any economy, in recent times, industrialized economies of the world are the top developed economies of the world. The examined results of manufacturing are in line with earlier researchers. Attiah (2019) examined the effect of the manufacturing of goods on the economic development of developing economies by using the ARDL model. Their results indicated that the manufacturing value-added is positively influencing the growth in developing economies. Haraguchi et al. (2016) indicated that a decrease in manufacturing in developing countries does not influence the economic growth, but it adversely influences the manufacturing capacity of the developing countries that causes low productions of goods that negatively influence the export of these economies.

The logistic index has a significant positive effect on the global supply chain, as 1 point increase in the logistic index can improve the global supply chain by $1.675 \%$ and $1.175 \%$ according to the results of GMM and FGLS models respectively. Aldakhil et al. (2018) have stated that the logistic performance causes an increase in export, and speed up the industrial production, which in turn helps the economy development. In another study, Khan et al. (2018) revealed that logistics positively affects the economy that includes manufacturing, FDI, and trade openness. The logistic indicator in the economy is now considered as the main element that helps to boost the overall economic activities. Improved logistic infrastructure attracts foreign investment, provides better-exporting facilities to the exporter around the globe through the supply chain (Khan et al. 2021).

Covid-19 is the pandemic outbreak around the world that not only claimed thousands of human lives but also halt the economic activities around the globe. Due to Covid-19, all the economic sector including manufacturing, services, tourism, and transportation. Most importantly, the global supply chain has been badly affected by this recent health crisis around the world. All economies are facing the problem of a slowdown in the economic activities that are adversely impacting the global supply chain, and the examined results also confirm the negative influence of the Covid-19 on the global supply chain in the countries under study. With every single increment in the active cases of Covid-19, there would be $0.0123 \%, 0.0102 \%$, and $0.0032 \%$ decline in the global supply chain as per fixed effect, random effect, and FGLS models respectively. In a recent study, Baldwin and Mauro (2020) have also revealed that international trade around the globe is experiencing a decrease of about $14 \%$ due to the Covid-19 from January to June 2020. The global supply chain is essentially influenced by the sudden shutdown and disturbance in the transportation sector that has negatively impacted the global supply chain (Zhang et al. 2019; Bouey 2020).

\section{Conclusion and managerial implications}

This study investigates the impact of Covid-19 and health expenditure along with the logistics and manufacturing industry on the global supply chain. Covid-19 is a global outbreak that has caused unprecedented health crises and shattered the social and economic activities around the globe. The results confirm the negative effects of Covid-19 on the global supply chain in the countries under examination. On one hand, all economies around the world are facing the shutdown of the industries and the slowdown in the economic activities that have adversely impacted the global supply chain; on other hand, upsurge in health expenditure is adding problems to this scenario. Results of the dynamic models i.e. GMM and FGLS demonstrate a significant negative effect of health expenditure on the global supply chain of the countries under study.

The recent crisis has dramatically affected all the sectors of the economy including the manufacturing industry and logistics industry, which are the two main pillars of the global supply chain. The dependence of the global supply chain on these industries is also evident from the results of the study. During Covid-19, sudden lockdown around the world has caused a tremendous decline in the aggregate demand of goods and services (especially transportation services), due to which the manufacturing and logistics industry has badly affected in the first half of 2020. This situation demands policymakers to react quickly, and take suitable policy measures to tackle this unprecedented pandemic 
driven economic crises. The global supply chain is the lifeline for the global economy; thus, it is recommended that cross-border trading activities should not be halted, rather governments and other agencies should devise smart lockdown strategies. Smart lockdowns can prove to be the best tradeoff between health hazards and economic issues.

One way to circumvent SC paralysis is to plan the possible timings, i.e. when to open and when to close the facilities at various SC tiers. Similarly, the proactive approach of management needs to be followed. A tough, but the increasingly significant proactive assignment is to accurately map the product's SCs beyond the first or subsequent supply tiers (Ivanov 2019). At this point, the emphasis would be shifted towards developing a redundancy that is flexible in nature so it would mold the SC systems less subtle to external ambiguities (Pavlov et al. 2019). A proactive approach may perhaps see an upsurge in the utilization of computerized manufacture and distribution arrangements. Viruses neither influence Robots nor are they indebted.

Last but not least specific SCs should be given priority due to being significant for the society and needs specific consideration from government authorities such as SC related to pharmaceuticals, specifically those reliant on the grocery retailers, biodiversity, and safety and healthcare segments.

Acknowledgement This research is partially supported by Shaanxi Social Science Foundation (2019S032); and National Social Science Foundation of China (19XJL004).

\section{References}

Aldakhil AM, Nassani AA, Awan U, Abro MMQ, Zaman K (2018) Determinants of green logistics in BRICS countries: An integrated supply chain model for green business. J Clean Prod 195:861-868

Altay N, Pal R (2014) Information diffusion among agents: implications for humanitarian operations. Prod Oper Manage 23(6): $1015-1027$

Anparasan AA, Lejeune MA (2018) Data laboratory for supply chain response models during epidemic outbreaks. Ann Oper Res 270(1-2):53-64

Apple (2020) Investor update on quarterly guidance [February 17, 2020]. Accessed 11 March 2020

Araz OM, Choi T-M, Olson D, Salman FS (2020) Data analytics for operational risk management. Decision Sci Forthcoming

Arellano M, Bond S (1991) Some tests of specification for panel data: Monte Carlo evidence and an application to employment equations. Review Econ Stud 58(2):277-297

Arvis JF, Mustra MA, Ojala L, Shepherd B, Saslavsky D (2012) Connecting to Compete 2012: Trade Logistics in the Global Economy. World Bank, Washington, DC. () World Bank. https:// openknowledge.worldbank.org/handle/10986/12689

Arvis JF, Mustra MA, Ojala L, Shepherd B, Saslavsky D (2010) Connecting to Compete 2010: Trade Logistics in the Global Economy. The World Bank, Washington, D.C.
Asteriou D (2009) Foreign aid and economic growth: New evidence from a panel data approach for five South Asian countries. J Policy Modeling 31(1):155-161

Attari MIJ, Hussain M, Javid AY (2016) Carbon emissions and industrial growth: an ARDL analysis for Pakistan. Int J Energy Sect Manag

Attiah E (2019) The role of manufacturing and service sectors in economic growth: An empirical study of developing countries. European Res Stud J XXII:112-127

Baldwin RE, di Mauro W (2020) Mitigating the COVID economic crisis (No. Centre for Economic Policy Research, BOOK)

Balle F, Vaidya A (2002) A Regional Analysis of Openness and Government Size. Appl Econ Lett 9(5):289-292

Banjoko S, Iwuji I, Bagshaw K (2012) The performance of the Nigerian manufacturingsector: A 52 year analysis of growth and retrogression (1960-2012). J Asian Bus Strategy 2(8):171-191

Bas M, Strauss-Kahn V (2014) Does importing more inputs raise exports? Firm-level evidence from France. Rev World Econ 150(2):241-275. https://doi.org/10.1007/s10290-013-0175-0

Benarroch M, Pandey M (2012) The relationship between trade openness and government size: Does disaggregating government expenditure matter? J Macroecon 34(1):239-252. https://doi. org/10.1016/j.jmacro.2011.11.002

Bernard AB, Blanchard EJ, Beveren IV, Vandenbussche HY (2012) Carryalong trade, NBER Working Paper 18246, National Bureau of Economic Research. Bild, 2020. https://www.bild.de/news/ inland/news-inland/coronavirus-rki-erklaert-ganz-italien-zumsperrgebiet-weltweit-nehmen-faelle-zu-69089326.bild.html. Accessed 10 March 2020

Bild (2020) https://www.bild.de/news/inland/news-inland/coronavirus-rkierklaert-ganz-italien-zum-sperrgebiet-weltweit-nehmen-faellezu-69089326.bild.html, Accessed 10 March 2020.

Bloom DE, Canning D, Jamison DT (2004) Health, Wealth, and Welfare. Finance Dev 31:10-15

Bloom DE, David Canning D (2005) Health and Economic Growth: Reconciling the Micro and Macro Evidence. Working Paper no. 42 (February), Center Democracy, Development, and Rule of Law, Stanford Ins Internat Studies, Stanford, CA. http://cddrl. stanford.edu

Bouey J (2020) Assessment of COVID-19's Impact on Small and Medium-Sized Enterprises: Implications from China

Buheji M, Cunha K, Mavrić B (2020) The Extent of COVID-19 Pandemic Socio-Economic Impact on Global Poverty. Glob Integr Multidisciplin Rev 10(4):213-224. https://doi.org/10.5923/j. economics.20201004.02

BSI (2014) Supply Chain Impact of 2014 Ebola Outbreak. https://www. bsigroup.com/LocalFiles/en-GB/supply-chain-solutions/resources/ Whitepaper\%20Ebola_10.14_7.pdf. Accessed 11 March 2020

Cabral S, Amador J (2015) A Bird's Eye View on the Impacts of Global Value Chains. https://doi.org/10.13140/RG.2.1.1502.3529

Calnan M, Gadsby EW, Konde MK, Diallo A, Rossman JS (2018) The response to and impact of the Ebola epidemic: Towards an agenda for interdisciplinary research. Int J Health Policy Manage 7(5):402-411

Cerdeira Bento JP, Moutinho V (2016) CO 2 emissions, non-renewable and renewable electricity production, economic growth, and international trade in Italy. Renew Sustain Energy Rev 55:142155. https://doi.org/10.1016/j.rser.2015.10.15

Chakravarty S, Mitra A (2009) Is Industry Still the Engine of Growth? An Econometric Study of the Organized Sector Employment in India. J Policy Modelling 31:22-35

Chen W, Clarke JA, Roy N (2013). Health and wealth: Short panel Granger causality tests for developing countries. J Int Trade Econ Dev 23(6):755-784. https://doi.org/10.1080/09638199. 2013.783093. 
Chou J, Kuo N-F, Peng S-L (2004) Potential impacts of the SARS outbreak on Taiwan's economy. Asian Econ Pap 3(1):84-99

COVID-19 contributions tracker (2020) Retrieved August 6, 2020, from https://www.who.int/emergencies/diseases/novelcoronavirus-2019/donors-and-partners/funding

Davidson R, MacKinnon JG (1993) Estimation and inference in econometrics. OUP Catalogue

Dee P, Findlay C (2006) Trade Facilitation: What, Why, How, Where and When? Working paper, Asian Development Bank, Manila

Devlin J, Yee P (2005) Trade logistics in developing countries: The case of the Middle East and North Africa. World Econ 28:435-456

Dollar D, Hallward-Driemeier M, Mengistae T (2004) Investment Climate and International Integration, Working paper No. 3323, The World Bank, Washington, DC

Dun, Bradstreet (2020) https://foreignpolicy.com/2020/03/04/blindsidedon-the-supply-side. Accessed 10 March 2020

Engemann M, Lindemann H (2013) Testing the O-ring theory for FDI, Working Paper 24, Deutsche Bundesbank

Eggoh J, Houeninvo H, Sossou G-A (2015) Education, health and economic growth in African countries. J Econ Develop 40(1):93-111

European Commission, Official Website. (2020). European Commission - European Commission. https://ec.europa.eu/info/index_en Accessed 03 August 2020.

Farag M, Nandakumar A, Wallack S, Hodgkin D, Gaumer G, Erbil C (2013) Health expenditures, health outcomes and the role of good governance. Int J Health Care Finance Econ 13(1):33-52

Farahani RZ, Lotfi MM, Rezapour S (2020) Mass casualty management in disaster scene: A systematic review of OR\&MS research in humanitarian operations. J. Oper. Res, Eur. https:// doi.org/10.1016/j.ejor.2020.03.005

Fernandes A (2007) Trade policy, trade volumes and plant-level productivity in Colombian manufacturing industries. J Int Econ 71(1):52-71

Gallup JL, Sachs JD (2001) The Economic Burden of Malaria. American J. Tropical Medicine and Hygiene 64(suppl. 1)85-96

Gani A (2017) The Logistics Performance Effect in International Trade. Asian J Shipp Logist 33(4):279-288. https://doi.org/10.1016/j. ajsl.2017.12.012

Ghani E, O'Connell SD (2014) Can Service be a Growth Escalator in Low Income Countries? World Bank Group Policy Research Working Paper 6971

Govindan K, Fattahi M, Keyvanshokooh E (2017) Supply chain network design under uncertainty: A comprehensive review and future research directions. Eur J Oper Res 263:108-141

Green LV (2012) OM forum-The vital role of operations analysis in improving healthcare delivery. Manuf Service Oper Manage 14(4):488-494

Greene WH (2011) Econometric analysis, 6th edn. Prentice-Hall, New Jersey

Griffiths WE, Judge GG, Hill RC, Lütkepohl H, Lee TC, (1985) The theory and practice of econometrics. Wiley

Halici-Tuluce NS, Dogan I, Dumrul C (2016) Is income relevant for health expenditure and economic growth nexus? I J Health Econ Manag 16(1):23-49. https://doi.org/10.1007/s10754-015-9179-8

Hanson GH, Mataloni RJ, Slaughter MJ (2005) Vertical production networks in multinational firms. Rev Econ Stat 87(4):664-678

Haraguchi N, Cheng CFC, Smeets E (2016) The Importance of Manufacturing in Economic Development: Has This Changed? World Development 93:293-315. https://doi.org/10.1016/j.worlddev. 2016.12.013

Haraguchi N, Cheng CFC, Smeets E (2017) The importance of manufacturing in economic development: Has this changed? World Dev 93:293-315

Hashmati A (2001) On the causality between GDP and health care expenditure in augmented Solow growth model. Department of Economic Statistics Stockholm School of Economics, Stock- holm
Haseeb K, Hussain, \& Jermsittiparsert. (2019) Impact of Economic Growth, Environmental Pollution, and Energy Consumption on Health Expenditure and R\&D Expenditure of ASEAN Countries. Energies 12(19):3598. https://doi.org/10.3390/en12193598

Hausman WH, Lee HL, Subramaniam U (2012) The impact of logistics performance on trade. Prod Oper Manag 22:236-252

Hoekman B, Nicita A (2010) Assessing the Doha round: Market access, transactions costs and aid for trade facilitation. J Int Trade Econ Dev 19:65-79

Hosseini S, Ivanov D, Dolgui A (2019) Review of quantitative methods for supply chain resilience analysis. Transp Res Part E 125:285-307

Hendricks K, Singhal V (2005) An empirical analysis of the effect of supply chain disruptions on long-run stock price performance and equity risk of the firm. Prod Oper Manag 25-53

International Energy Agency (IEA) (2020) Global Energy Review 2020, IEA, Paris https://www.iea.org/reports/global-energy-review2020. Accessed 17 June 2020

ISM (2020) [online] https://weareism.org/coronavirus-ism.html. Accessed 28 March 2020

Ivanov D (2019) Disruption tails and revival policies: A simulation analysis of supply chain design and production-ordering systems in the recovery and post-disruption periods. Comput Ind Eng 127:558-570

Ivanov D (2020) Predicting the impacts of epidemic outbreaks on global supply chains: A simulation-based analysis on the coronavirus outbreak (COVID-19/SARS-CoV-2) case. Transp Res Part E Logist Transp Rev 136:101922. https://doi.org/10.1016/j. tre.2020.101922

Ivanov D, Dolgui A (2020) A digital supply chain twin for managing the disruptions risks and resilience in the era of Industry 4.0. Prod. Planning Control forthcoming

Johanis D (2007) How Toronto Pearson International Airport applied lessons from SARS to develop a pandemic response plan. J Bus Contin Emerg Plan 1(4):356-368

Kar M, Taban S (2003) The impacts of the disaggregated public expenditure on economic growth. Ankara Univ Fac Political Sci 53(3): 145-169

Kasahara H, Rodrigue J (2008) Does the use of imported intermediates increase productivity? Plant- Level evidence. J Dev Econ 87(1):106-118

Katuria V, Raj SN (2009) Is manufacturing an engine of growth in India? Analyis in the post nineties. Paper for the UNU-WIDER/ UNU-MERIT/UNIDO Workshop, Pathways to Industrialisation in the 21st Century. New Challenges and Emerging Paradigms, Maastricht 22-23 October

Khan SAR, Sharif A, Golpira H, Kumar A (2019) A green ideology in Asian emerging economies: From environmental policy and sustainable development. Sustain Dev 27(6):1063-1075

Khan SAR, Zhang Y, Anees M, Golpîra H (2018) Green supply chain management, economic growth and environment: A GMM based evidence. J Clean Prod 185:588-599

Khan SAR, Zhang Y (2020a) Assessing the eco-environmental performance: an PLS-SEM approach with practice-based view. Int J Logist Res Appl. https://doi.org/10.1080/13675567.2020.1754773

Khan SAR, Zhang Y, Belhadi A, Mardani A (2020b) Investigating the effects of renewable energy on international trade and environmental quality. J Environ Manage 272:111089. https://doi.org/10.1016/j. jenvman.2020.111089

Khan SAR, Zhang Y, Golpira H, Sharif A, Mardani A (2021) A state-of-the-art review and meta-analysis on sustainable supply chain management: Future research directions. J Clean Prod 278:123357

Khan SAR, Zhang Y, Kumar A, Zavadskas E, Streimikiene D (2020) Measuring the impact of renewable energy, public health 
expenditure, logistics, and environmental performance on sustainable economic growth. Sustain Dev

Ke X, Saksena P, Holly A (2011) The determinants of health expenditure: A country-level panel data analysis. Working paper of the Results for Development Institute (R4D). Geneva: World Health Organization. www.resultsfordevelopment.org. Accessed 11 August 2017

Koyuncu M, Erol R (2010) Optimal resource allocation model to mitigate the impact of pandemic influenza: A case study for Turkey. J Med Syst 34(1):61-70

Kraus S, Clauss T, Breier M, Gast J, Zardini A, Tiberius V (2020) The economics of COVID-19: Initial empirical evidence on how family firms in five European countries cope with the corona crisis. Int J Entrep Behav Res 26(5):1067-1092. https://doi. org/10.1108/IJEBR-04-2020-0214

Lakshmanan TR, Subramanian U, Anderson W, Leautier F (2001) Integration of Transport and Trade Facilitation. Directions in Development, Washington, DC: World Bank

Limao N, Venables AJ (2001) Infrastructure, geographical disadvantage, transport costs, and trade. World Bank Econ Rev 15(3):451-479

Linton T, Vakil B (2020) Coronavirus is proving we need more resilient supply chains. Harward business review, March 5, 2020, https:// hbr.org/2020/03/coronavirus-is-proving-that-we-need-moreresilient-supply-chains. Accessed 10 March 2020

Luttermann S, Kotzab H, Halaszovich T (2020) The impact of logistics performance on exports, imports and foreign direct investment. World Rev Intermodal Transp Res (WRITR) 9(1)

Maddala GS, Lahiri K (1992) Introduction to econometrics, vol 2. Macmillan, New York

Melitz M (2003) The impact of trade on intra-industry reallocations and aggregate industry productivity. Econometrica 71(6):1695-1725

Mofijur M, Fattah IMR, Alam MA, Islam ABMS, Ong HC, Rahman SMA, Najafi G, Ahmed SF, Uddin MDA, \& Mahlia TMI (2021) Impact of COVID-19 on the social, economic, environmental and energy domains: Lessons learnt from a global pandemic. Sustain Prod Consum 26:343-359. https://doi.org/10.1016/j. spc.2020.10.016

Newey WK, West KD (1994) Automatic Lag Selection in Covariance Matrix Estimation. Rev Econ Stud 61(4):631-653

Newhouse JP (1992) Medical care costs: How much welfare loss? J Econ Perspect 6(3):3-21

OECD Economic Outlook, August (2020) OECD. https://www.oecd. org/economic-outlook/August-2020.

Oni LB (2014) Analysis of the growth impact of health expenditure in Nigeria. J Econ Finance (JEF) 3(1):77-84

Pavlov A, Ivanov D, Werner F, Dolgui A, Sokolov B (2019) Integrated detection of disruption scenarios, the ripple effect dispersal and recovery paths in supply chains. Ann Oper Res. https://doi. org/10.1007/s10479-019-03454-1

Portugal-Perez A, Wilson JS (2012) Export performance and trade facilitation reform: Hard and soft infrastructure. World Dev 40:1295-1307

Rao P, Griliches Z (1969) Small-sample properties of several two-stage regression methods in the context of auto-correlated errors. J Am Stat Assoc 64(325):253-272

Retaildive (2020) https://www.retaildive.com/news/the-impact-of-thecoronavirus-on-retail/573522/. Accessed 10 March 2020

Rodrik D (1998) Why do more open economies have bigger governments? J Political Econ 106:997-1032

Saslavsky D, Shepherd B (2012) Facilitating international production networks: The role of trade logistics. Policy Research Working Paper 6224, World Bank

Simpson D (2012) Knowledge resources as a mediator of the relationship between recycling pressures and environmental performance. J Clean Prod 22(1):32-41
Statista-The Statistics Portal (2020) Statista. https://www.statista. com/. Accessed 22 July 2020.

Su D, Yao Y (2017) Manufacturing as the key engine of economic growth for middle-income economies. J Asia Pacific Econ 22(1):47-70

Szirmai A (2009) Industrialisation as an Engine of Growth in Developing Countries, 1950-2005. UNU-MERIT, working paper, 10.

Szirmai A, Verspagen B (2015) Manufacturing and Economic Growth in Developing Countries, 1950-2005. Struct Change Econ Dyn 34:46-59

Tregenna F (2007) Which Sectors Can be Engines of Growth and Employment in South Africa? An Analysis of Manufacturing and Services. Paper presented at the UNU-WIDER CIBS Conference on Southern Engines of Global Growth, Helsinki, 7-9 September

Ventelou B, Arrighi Y, Greener R, Lamontagne E, Carrieri P, Moatti JP (2012) The macroeconomic consequences of renouncing to universal access to antiretroviral treatment for HIV in Africa. PLoS ONE 7:e34101

Vos R, Martin W, Laborde D (2020) How much will global poverty increase because of COVID-19? Available from https://www. ifpri.org/blog/how-much-will-global-poverty-increase-becausecovid-19

Wakasugi R (2007) Vertical intra-industry trade and economic integration in East Asia. Asian Econ Pap 6(1):26-39

WHO Coronavirus Disease (COVID-19) Dashboard. (2020). https:// covid19. who.int Accessed 06 August 2020.

Windmeijer F (2000) Moment conditions for fixed effects count data models with endogenous regressors. Econ Lett 68(1):21-24

World Development Indicators DataBank (2020) https://databank. worldbank.org/reports.aspx? source=world-developmentindicators. Accessed 23 July 2020.

World Economic Forum (2020) As Coronavirus Spreads to Poorer Countries, Here's How the World Can Help. Online available at: https:// www.weforum.org/agenda/2020/03/coronavirus-developingcountries-inequality-debt-oxfam/. Accessed 4 April 2020

Worldometers (2020) https://www.worldometers.info/coronavirus/ country/china/

WTO (2016) World trade organization statistics: Trade and tariff data. Accessed on June 2016

Xu S, Zhang X, Feng L, Yang W (2020) Disruption risks in supply chain management: A literature review based on bibliometric analysis. Int J Prod Res. https://doi.org/10.1080/00207543. 2020.1717011

Yan Y, Shin WI, Pang YX, Meng Y, Lai J, You C et al (2020) The First 75 Days of Novel Coronavirus (SARS-CoV-2) Outbreak: Recent Advances, Prevention, and Treatment. Int J Environ Res Public Health 17(7):2323

Yip TL (2012) Seaborne Trade between Developed and Developing Countries. The Asian J Shipp Logist 28(3):369-389

Yumuşak IG, Yıldırım DÇ (2009) An econometric examination over the relation between health expenditure and economic growth. J Knowl Econ Knowl Manag IV:57-70

Zhang Y, Khan SAR, Kumar A, Golpîra H, Sharif A (2019) Is tourism really affected by logistical operations and environmental degradation? An empirical study from the perspective of Thailand. J Clean Prod 227:158-166

Publisher's Note Springer Nature remains neutral with regard to jurisdictional claims in published maps and institutional affiliations. 